\title{
RELATIONS BETWEEN EUROPEAN PARLIAMENT WITH THE NATIONAL PARLIAMENTS OF THE EU MEMBER STATES
}

\author{
by Joanna Marszałek-Kawa \\ European idea is in the final stage of implementation. \\ Ioday's decisions will shape the face of tomorrow's Europe. \\ J. Janing
}

According to Montesquieu tripartite system, formed in the European constitutionalism, the organs of authority, in a democratic state, affect each other in an inhibitory way, balancing mutually. Traditionally, it is understood that the executive power is performed by the Head of State (monarch, president) and government, legislative power belongs to the parliament, whereas the judicial power is exercised by independent courts. Analyzing the political reality of member states it is necessary to note, that the executive participates in the national legislative processes more actively, for example, through executing constitutionally granted right of legislative initiative (usually together with deputies), by issuing acts with the power of law, or incorporating Community directives into the internal legal order.

Parliament - the collective legislative body originating from the direct elections represents the will of its sovereign - the nation - in the lawmaking process. In all European countries, both position as well as competence 
of representative organs underwent a serious evolution at the turn of the centuries - from the body convened to elect the ruler, parliament as a representation of states fulfilling functions of advisory and legislative character, however, under the control of the king, up to the present position of the Chamber, as one of the most important bodies of state authority (in many countries the most important, depending on adopted political system).

Legislative function of national parliaments in connection with accession to EU structures, and what is closely related, with the duty of accepting all principles governing Communities resulting both from founding treaties of the European Union (of the primary law), as well as from the current law created by Community bodies (so-called secondary legislation - among others of regulations, ${ }^{1}$ directives, decisions, opinions, recommendations ${ }^{2}$ ), was significantly reduced. In today's European reality, in connection with the supremacy of EU law, parliaments play a serious role in the transposition of Community directives, rather than stipulating internal normative acts.

Adoption of Community law is one of the routes of the realization of the obligations of the Member States to EU structures. The meaning of national legislative bodies in this range is auxiliary, menial character. The activity of Parliament is not therefore the execution of own competences and the realization of the obligations of the State. Parliaments are appearing in the role of the co-performer of obligations. Rules for their implementation define the same Communities. As a result infringement of those rules by Parliament or as a result of ceasing to conduct the transpositive

\footnotetext{
1 Regulation and decisions adopted by Community bodies are binding legislative acts about the direct effect in member states of the Union, does not require any activity on the side of the national parliaments. In case of directives (also acts of binding force) however their transposition is necessary to internal order of states (incorporation). European law does not specify the methods and forms of transposing, leaving that question for the sovereign decisions of national representative bodies. The opinions and recommendations are non-binding.

2 See more: A.G. Toth (ed.), The Oxford Encyclopedia of European Community Law, vol. I, Institutional Law, Oxford 1991.
} 
process, is arising a need to bear responsibility for such an offence on EU arena $^{3}$ on the side of the member state.

It should be also emphasized that, the very organization of the legislative process in the transposition of communities' standards to domestic order remains the domain of the member state. European Union does not impose any of their solutions on the national parliaments, with the exception of one generally named term which was appointed in art. F.1. of the European Union Treaty, ${ }^{4}$ namely the obligation to respect democratic principles and the rule of law. Such laconic designation of rules, dealing with Community acts, affects the fact that in legislative practice the legislative competences, in this area, are carried out repeatedly by the authorities of executive power. ${ }^{5}$

National parliaments of the Member States fulfill an important role in shaping the country's foreign policy, ratifying treaties ${ }^{6}$ (incorporation, amending and accession) and international agreements concluded with other EU countries, Communities themselves, as well as with the states remaining outside the EU. Making a decision about the ratification of a treaty, representative bodies, apart from having the right to full approval of the above Act, are also exercising the right to reject it. ${ }^{7}$ By carrying out the tasks by the national parliaments, in the range of giving its consent to conclude determined treaties by the state (of international agreements)

3 D. Olejniczak, Funkcja prawodawcza i kontrolna parlamentów krajowych państw członkowskich Unii Europejskiej - analiza porównawcza, BSE report, No. 127, p. 8.

4 I.e. of the Maastricht Treaty; see more: D. O'Keeffe, T.M. Twomey (ed.), Legal Issues of the Maastricht Treaty, London 1994.

5 Considering the strong position of the executive political systems in some EU countries, the role played by the representative bodies in the transposition of Community law standards may be small. In this place one could show the example of France, where, in connection with the government's qualifications to issue legislative ordonnances, which shall be signed by the President, a legislative and National Assembly competence underwent a serious restriction, including adoptive one.

6 See more: J. Galster, C. Mik, Podstawy europejskiego prawa wspólnotowego. An outline of lecture, Torun 1998.

7 See more: T.C. Hartley, European Community Law, Oxford 1991; D. Lasok, J.W. Bridge, Law and the Institutions of the European Communities, London-Dublin-Edinburgh 1991. 
are effecting the inspection of directions conducted by the executive of the foreign policy of the state, simultaneously.

Moreover, it is worth mentioning that, national legislatures of member states strongly affect the shape of the system existing in a given state exercising the right to pass new fundamental acts (as well as to implement the changes). In some constitutional systems this law is being shared with the society. On the basis of the Constitution, the sovereign has the right to express his opinion in the matter of draft of the new constitution in the referendum ${ }^{8}$ organised especially for this purpose (beside the right of the constitutional initiative - so-called people's initiative).

At discussing the position of member states' parliaments in connection with participation in EU structures, another, not less important competence is worth highlighting. Legislatures have the possibility to influence the shape of the law created in the Union. This entitlement is being exercised by legislative bodies in the form of the active involvement in Community supranational structures. By joining the organization of this type, parliaments have the possibility to carry out control tasks and get specific, material basis for the execution of the right to information.

In May 1989, the Conference of Presidents of the national parliaments of Member States of the European Union and President of the European Parliament, held in Madrid, decided about the creation of $\mathrm{COSAC}^{9}$ - the Commission of European national parliaments and the European Parliament Conference. On the basis of the settlements, it was established in Paris on 16-17 November 1989.

In the literature one can come across the definition of COSAC, adopted by EP, as Conference of Bodies Specialized in Community Affairss. Currently, however, it has a historical dimension and comes from the original French name Conférence des Organes Specialisés dans les Affaires Communautaires, and is not usually used in the full name.

COSAC constitutes the arena of unofficial exchange of views, on topics concerning not only Community, conducted between the representatives

8 This referendum can have consultative, as well as deciding character.

9 At first, meetings of the Conference were held every two years. As a result of the Lisbon post-conference arrangements from 1999 they were organized annually. 
of national representative bodies and Euroassembly. ${ }^{10}$ So the conference is not a decision-making body in the sphere of EU policy. ${ }^{11}$ Therefore, the positions adopted by the parliaments as part of the Conference do not constitute a binding proposal on state legislative bodies. ${ }^{12}$ They also do not settle their opinion on a given issue. They only fulfill an interacting purpose. They indicate the priorities approved by the parliaments of the EU representation.

Conference Committee for European Affairs uses the right to transfer its all proposals to European Parliament, European Union Council and European Commission. Another COSAC's competence results from above. The Conference specifying common will of the parliament representatives of the Fifteen countries, has the right to initiate legislative changes within the domain of standards of safety, justice and the principle of subsidiarity, as well as directly affecting rights and freedom of European Union Citizens.

Currently, in accordance with Article 1.1 and Article 2. of regulations, Conference Committee for European Affairs holds two meetings, annually, in the second half of each presidency in the state exercising its. COSAC meet in extraordinary meetings convened also on the initiative of its members supported by an absolute majority of the Presidents of the national parliamentary bodies for the EU matters and for an appropriate authority of the Institutional Committee of the European Parliament.

COSAC meetings are being organized by the national parliament of the state which assume the Presidency in the European Council. The host of the Conference covers all costs associated with its organization.

Six-person delegations of organs specialized in Community matters of national parliaments are participating in the Conference designated by

\footnotetext{
10 In the case of bicameral national parliaments of the two chambers, each sends their representatives.

11 COSAC is not a decision-making body, but consultative and coordinating, which is making a decision by way of the consensus.

12 In the preamble, adopted in Helsinki in October 1999 of COSAC regulations, which came into force on 2 January 2000, it was concluded that opinions formulated by Conference are not binding for national parliaments and do not prejudge their position.
} 
national parliaments ${ }^{13}$ and representatives of the European Parliament. COSAC deliberations are public, except for the situation when they are made secret. ${ }^{14}$

A so-called troika is preparing the COSAC agenda with the approval of the European Parliament. Troika consists of:

- the President of the Committee for European Affairs of the country currently holding the presidency of the European Council;

- the President of the Committee for European Affairs of the State, which had previously exercised the presidency of the European Council;

- and the President of the Committee for European Affairs from the country which will be in the next round hold the Presidency in the European Council.

During the meetings of the Conference, first and foremost, issues related to the increase of effectiveness of inspection carried out by national parliaments over the governments on Union affairs and issues of place and role of national parliaments in the European Union, as well as in the framework of COSAC.

The deliberations of the Conference are organized and funded by the parliament of the country holding the presidency at this time in the Communities. The importance of the COSAC meeting depends on both the host, the funds allocated for this purpose, as well as the proposed problems and participating guests. Especially ceremonial was, for example, XI Conference held in Bonn on 24-25 October 1994, devoted to issues of internal security, Europol, the environment, the principle of subsidiarity, ratification of the accession treaties for Austria, Sweden and Finland. In the Conference took part, among others, Helmut Kohl (the then Chancellor of Germany), Klaus Topfer (Federal Environment Minister), Rexrodt Gunter (Minister of Economy). ${ }^{15}$

13 Two-chamber parliaments send three representatives from every chamber. Representatives from the Polish parliament, alongside other parliaments' representatives of the candidate countries, were invited to COSAC meetings as observers from 1997.

14 Article 4.1 of the COSAC rules of procedure.

15 R. Grzeszczak, The role of national parliaments in the integration process in the framework of the European Union, "European Communities" 2000, No. 9 (109), p. 10. 
Currently one does not find the opinions that question the importance of the Conference of Committee for European Affairs. More and more frequently, opinions postulating ${ }^{16}$ its conversion into a second chamber of the European Parliament ${ }^{17}$ can be heard. In the past, however, it was different, particularly in view of the miserable tangible effects of Conference meetings. Confirmation of its position, as well as the powers to formulate and transmit opinions on Community affairs to institutions of the EU, COSAC waited in the provisions of the above-mentioned Protocol on the role of national parliaments of the Member States of the European Union annexed to Treaty of Amsterdam.

National legislative bodies send their representatives for the Conferences of Presidents of Parliaments of the European Union ${ }^{18}$ organized every year. Although those meetings did not have decision-making competence tying for member states, they play significant role. They constitute additional parliamentary control body over the actions, in the scope of foreign as well as Community policy, taken by Member States' governments. The Conference of Presidents of the EU Parliament constitutes unofficial platform for exchange of views on EU issues and is a forum of the cooperation between national parliaments and EP. ${ }^{19}$

Just like the Conference Committee for European Affairs, the Conference of Presidents of Parliaments of the EU also activates the efforts of national bodies representatives, encourages them to take action in the European Union. Thanks to these efforts is increases the ability of national legislative bodies to express their will, opinions and as a result influence the shape of the Community law and directions of the Union policy.

Representatives of national parliaments, including representatives of assemblies of all member states of the European Union, are also meeting

16 In relation to the need to conduct institutional reforms in the Union in the aspect of its further extension for a further Member States.

17 There are also other proposals for the creation of the Second Chamber of the European Parliament, in a different way governing its legal basis.

18 The first meeting of the Conference of Presidents of Parliaments was held in 1963 and the next in 1973. Organization of the Conference resumed again in 1981.

19 European Parliament Fact Sheets - The European Parliament: relations with the national parliaments, www.europarl.eu.int/factsheets/1 35 en.htm, 27.06.03. 
during the sessions of the Inter-Parliamentary Union (IPU) ${ }^{20}$ organized from 1889. The main objective of the EU is, among others, to strengthen personal contacts between MPs of all representative bodies and to promote peace building. So far, this institution, although undoubtedly constitutes the valuable initiative, did not bring significant effects, in practice one should assume that it plays rather slight role.

On the margins, it should be noted that in the aspect of democratic deficit afflicting community institutions, such initiatives are extremely valuable. They widen the participation of representatives directly chosen by societies of the Fifteen (deputies to the national parliaments) in deciding on current issues and problems of the Union. They make it possible to influence the future and progress of Communities.

Examining decision-making and test procedures functioning in the European Union one comes to the conclusion that the possibility of carrying out effective supervision of government actions in the structures of the Community by the national parliaments is illusionary. At present, for the very reason, there is an evident bigger activity of representative organs of member states in the sphere of the inspection of actions by the Prime Minister and by ministers before the adoption of the relevant act of the $\mathrm{EU}$, so already at the preparatory stage in the EU ${ }^{21}$. The problem indicated above has been noticed by politicians and commentators of the public life in Communities. Philippe Séguin, who during the Conference of Presidents of Parliaments that was held in Athens on 11 April 1994, emphasized that "many enough think democracy of EU depends on the degree of incorporating national parliaments into the process of Community decision making"22, is also an exponent of this problem. 1922.

20 Poland has been participating in meetings of the Inter-Parliamentary Union since

21 By defining the borders of executive actions, parliaments are trying to have an influence on decisions made at the Council of European Union; see more: R. Grzeszczak, op.cit., p. 6

2222 Cited by N. Ameline, Le rôle des parlements nationaux dans la construction européenne, „Rapports d'information de l'Assamblée Nationale”, No. 1437, Paris 1994, p. 10; M. Kruk, E. Popławska (ed.), Parlamenty a integracja europejska, Warsaw 2002, p. 195. 
Following this challenge, the national parliaments of the Member States compensate for the limitation of the field of its own legislation, through the expansion of test instruments carried out mainly with reference to organs of the executive power. Supervising the actions of the executive in the area of Community policy, legislative bodies are trying to provide themselves with complete influence on shaping the European policy. They aspire to hold and guarantee certain, legally defined balance in the actions taken by government entities, thus securing the balance between the authorities existing in the country.

Classical parliamentary control of the government's actions in the field of pursued EU policy, in Great Britain, for example, is being exercised with such instruments as oral and written questions, requests for clarifying different issues, parliamentary questions, considering budget projects and legislative projects concerning the Union. But these are mostly individual initiatives of individual parliamentarians, which do not entail permanent and regular supervision of decision-making process in the framework of the European Communities. In the case of considering bills and budget projects in the Community, Parliament also performs only ad hoc tasks within the control of a posteriori. In Belgium the situation of the parliament is developing a little bit more favorably. Members of the European Parliament have the right to ask information questions to members of government. Special information system has also been developed. It allows for instant transmission of information on the agenda to parliament, which will be in force during the meetings of the Council of the European Union. ${ }^{23}$ The House of Representatives, before every summit of the European Council, can prepare a debate ending with the adoption of a resolution requiring the government to defend a particular position at a meeting of Heads of State and Government.

This practice of carrying out parliamentary debates before and after the European summit, as well as the obligation to submit reports by the government for its actions in the Union (in the Netherlands, the government systematically presents written reports to parliaments), certainly contributes

23 In Austria, for example, the government has the responisbility to inform the members of National and Federal council about all executive's transactions within EU. 
to the improvement of political control. ${ }^{24}$ Undoubtedly, membership in the EU structures resulted in reducing the rights created by the national parliaments. ${ }^{25}$ It contributed to moving union tasks belonging traditionally to legislative assemblies of member states in favor of the institutions of the European Union. At the same time it led to an increase of the importance of representative bodies' control functions. Austria's experience, coming from the membership in the Union, shows that participation in the Community structures causes the necessity to carry out changes in the field of competences of national representative bodies. Firstly, it is related to European dream of reducing the "democratic deficit", Secondly, it results from, standing on the side of national parliament, necessity to compensate for the loss of competences after joining the EU.

As it was mentioned above, determining function which is the essence of parliamentary activity, is performed in the European Union mainly by the Council of the European Union, i.e. the institution consisting of representatives of the national executive branches (executives). As Jan Barcz accurately argues, it is clear that in this situation "the influence of national parliament in intra state decision making, associated with integration issues, is increased". Barcz also emphasizes that Austria constitutes a good example of appropriate solutions to this problem. "A legal framework for cooperative interaction of parliament and government in the affairs of European integration"26 was created there.

Constitutions obligatory in 15 EU Member States are defining the government's responsibilities in union affairs, in particularly sending the union

\footnotetext{
24 Nadzór parlamentarny nad ustawodawstwem wspólnotowym w Wielkiej Brytanii, translation of the report of a member of the Belgian House of Representatives, Van Der Maelen, Bureau of Research of the Chancellery of the Seym, September 1995, Materials and Documents, No. 159, pp. 1-5.

25 The reduction of the laws constituted by national parliament is a result of devolving part of its legislative competence upon EU, after joining the Union. The research shows that the Communities take over $2 / 3$ of the issue covered by legislative competence of national legislatures; see more: S. Griller, Zür Demokratischen Legitimation der Rechtsetzung In der EU, JfR 1995, notebook 3, p. 165. In turn, secondary legislation acts in Communities are established by the Council of the European Union.

26 J. Barcz, Parlament a Unia Europejska. Analiza prawna na przykładzie doświadczeń Austrii, Warsaw 1999, p. 43.
} 
acts (sometimes the competent parliamentary committees) to parliaments, with reservation that handing over documents should take place within the time that enables the parliament to take a stance in the subject matter. Through securing the ability to analyze, debate and review Community documents, yet at the planning stage, legislative bodies guaranteed for themselves the possibility to influence the creation of EU law acts. ${ }^{27}$

In the aspect of membership in the European Union, some legislative bodies gained the duty to consult certain actions in the field of Community policy. It is necessary to emphasize, that in this field, especially evident is the activity of parliamentary committees appointed by representative bodies. The duty to consult may be executed by the parliament, or by Parliamentary committees in two ways, namely, by obtaining:

1. bargaining mandate in the form of a non-binding recommendation (e.g. Belgium, Sweden, Greece);

2. related mandate, i.e., granted in the form of a binding instruction (e.g. Denmark, partly Germany, Finland or the Netherlands, Austria).

Considering the control function performed by national Parliaments, it is necessary to emphasize, that effective control of the executive can be conducted only under the conditions of permanent and full access to information, guaranteed by Parliament. Methods of supervising the actions of executive power, as well as regulating the duty to convey the information, by government to parliament, about preparing EU laws (as well as their range), are determined by the national agenda of each country. Regulations of this type can be placed by the legislature so in articles of the constitution, as well as to arise from acts, or parliamentary rules adopted in the form of resolutions.

National parliaments gradually began to express the concern about the loss of the field of their influences. Therefore, they are trying to strengthen the national control over the activity of their governments and bring together relations with the European Parliament treating it as a way to compensate oneself for limiting the area of the influence.

\footnotetext{
27 D. Olejniczak, op.cit., p. 10.
} 
Declarations No. 13 and 14, enclosed to the Maastricht Treaty, account for:

- respecting the place of national parliaments in the European Union activities (governments must inform the national parliaments about legislative proposals „in the appropriate time”);

- cooperation between the EP and national parliament conducted in the form of regular meetings;

- emphasizing the importance of the control of national parliaments over activity of governments, as a result of constitutional reforms;

- they indicate that the committees specializing in European issues play a major role in the development of cooperation with the EP;

- the protocol on the role of national parliaments annexed to the Amsterdam Treaty extends the field of activity of the national representative bodies in the $\mathrm{EU} ; 28$

Moreover, „conference (COSAC - note by author) considers, it is important to encourage the national parliaments to a greater participation in the activities of the European Union". In literature it is also indicated that, for this purpose, the exchange of information between national parliaments and European Parliament should be expanded. Therefore, the governments of member states should assure, among others, that national legislatives receive legislative proposals of European Commission, in time which would allow to familiarize with them, or to study them. ${ }^{29}$

Protocol, on the role of national parliaments annexed to the Treaty of Amsterdam, extends the field of activity of the national representative bodies in the EU. According to the Protocol on the role of national parliaments in the European Union, that constitutes the Annex to the Amster-

28 European Parliament Fact Sheets - The European Parliament: relations with the national parliaments, www.europarl.eu.int/factsheets/1 35 en.htm, 27.06.2003.

${ }_{29}$ More effective political control would provide the certainty justification attached to any proposal of the European Commission, which shows that intervention is carried out at the appropriate level (control of subsidiarity); see more widely: Parliamentary supervision of the community legislature in Great Britain, translation report by Van Der Maelen, a member of the Belgian House of Representatives, the office of the Seym, the Office of Studies and expert opinions, September 1995, Materials and Documents, No. 159, pp. 3-5. 
dam text of the Treaty ${ }^{30}$, on 2 October 1997, all consultation documents ${ }^{31}$ of Commission are promptly forwarded to national parliaments of the Member States. Next, the Article 2 of the Protocol determines, that the drafts of legal act, prepared by Commission, are passed on to national governments in time, so they are able to pass them on to legislative bodies in order to examine them. The above mentioned decisions of the Protocol designate both the boundaries of information, which is transmitted to member states' parliaments, as well as determine the responsibilities of government in this range.

In conclusion, appropriate supervision over the government's actions and providing an appropriate place for the government, among national authorities as well as on Community arena is, therefore, not possible without a corresponding information - supplied by the Government about all significant union affairs, in particular including their international context, of integration, etc.

In addition, the parliament must be able to express their evaluations, opinions, views on all important issues, from its point of view. It should also be able to control the acknowledgement, by the executive, of its opinions during the negotiations and voting on union forum. Distinct defining of the fields, in which the government should absolutely hold the parliamentary position (giving up the position is possible only with the parliament's consent), is conductive to strengthening the position of legislative in process of the EU - especially when it comes into

Full control of government by parliament does not provide, however, only and exclusively, the same transmission by the executive of Community documents to the legislature. The Union is an extremely efficient "producer", it published various thousands acts per year. The fact that the national bodies representative will receive appropriate documentation to the EU does not mean yet, that are adequately informed. Does not guarantee the active participation of parliamentary bodies in decision-making process. As writes J. Barcz, have yet to be met two conditions:

30 Under the Treaty of Amsterdam "Protocol of the role national parliaments ..." was enclosed to the European Union Treaty and to Treaties on creating the Communities.

31 Green and white papers and communications. 
- firstly, one should create a data bank, which task will be a filing of documents, their description and correlating with Community appropriate procedures;

- secondly whereas, one should guarantee the adequate cooperation of the government with the parliament, so that members of the government are obliged to provide appropriate fora of negotiations on the specific case in the European Union, as well as of presenting the departmental, or governmental position in the given sphere. ${ }^{32}$

Carrying out the control of the activities of the organs of Executive branch, also in the area of the Community policy, Parliaments shall benefit from the competence owned by them to conduct debates on the EU acts. This entitlement includes also a right to organize discussion on these Community documents, which weren't submitted to national legislative bodies by the government in order to address the specific position.

The national representative bodies supervise of executive also by:

- leading the monitoring of actions taken by its;

- monitoring the implementation of agreements concluded by the government with other Member States of the European Union;

- controlling the degree to which the government took into account the position of parliament (the parliamentary committee) in the course of its European policy;

- directing at members of the government inquiries and the parliamentary questions, to which answers are given, both in meetings of relevant committees, such as also in the time (open) of plenary sessions of the parliament carried out under eye public opinion; demanding from representatives of the executive of introducing the consequence to the chamber (e.g. financial, of changes in the domestic legislation), what for the national legal order may result in the adoption of the act of the EU. ${ }^{33}$

Parliaments are aspiring for providing oneself with the possibility of analysing and reviewing acts still taken in the communities on preparatory stage. The aim of these efforts is, of course, firstly, guaranteeing

\footnotetext{
32 J. Barcz, op.cit., pp. 44-45.

33 D. Olejniczak, op.cit., p. 13.
} 
adopted by Parliament position in the case of chance of the realization by the government on the forum of the European Union, secondly, providing oneself with the indirect effect to the shape of created of Community law.

As already stated above in the literature indicates that the parliaments, realizing being entitled them control function, can make it into the twofold way, depending on the position occupied in relation to the executive. Tighter bound by the executive in today's parliamentary practice, however, more rarely appears. Only in Denmark ${ }^{34}$ Folketing may boast an entitlement co-decision in the national Community policy. Because has the right to demand from the government of taking actions according to fixed by oneself the negotiating mandate defining the limits of representation in the conduct of an EU policy. The position of the Danish Committee for European Affairs (Europaudvalget), accepted on weekly meetings being held on Fridays, is binding the government in negotiations. During each deliberations of the committee present are representatives of the Government, who shall inform its members, inter alia, of its position on the issues which are subject of negotiations in the upcoming week, the Union acts adopted with immediate effect on the national agenda, of Community acts that require transposition into national law or whether the documents on which is currently being held in the debate in Community structures. Parliament shall give government a binding mandate. In line with the principle of the Danish parliamentary system political responsibility of the Government before the chamber, executive shall proceed in accordance with its mandate granted. If, in practice, the necessity to exceed the boundary of authorization occurs, each of its possible violation has to be consulted with Folketing. ${ }^{35}$

\footnotetext{
34 Also, for example, in Finland, the position of the Great Commission in the Community matter is binding for the government and its violation results in the obligation, on the side of government, deposit by proper representative of the government either oral or written explanation. Matters relating to the Common Foreign and Security Policy of the European Union are within the competences of the Commission for Foreign Affairs of Edyskunta, see more widely: http:biurose.serjm.gov.plo/teksty/ip78p-a2.htm.

35 Ibidem, pp. 11-12.
} 
In the overwhelming majority of the EU member states, the position of the parliament has only consultative character. This means that the representative body, in a recommendation made it should, however, be noted that, in constitutional reality the governments are trying to take into account the parliament's opinion, due to the fact, that the position adopted by the representative body, is the opinion of the majority, i.e. the opinion, whose realization, or not, can influence the length of government's mission.

Considering the fulfillment of control function, by governments, it needs to be emphasized that its importance is limited by traditional property of the executive power in the field of conducting foreign policy of the country. It is also weakened by tendency, existing in the Community legislative practice, to transfer initiative law to national governments in the aspect of transposing. The EU documents to internal order ${ }^{36}$ and transfer other executive qualifications onto the executive bodies. Also the union legislative procedure, that minimalizes the participation of parliaments in legislative process, and in connection with direct regulations completely removes it, contributes to that.

Systemic reality of the Member States shows that governments many times are refraining themselves from the transmission of information for national representative bodies or transmit them only at random. It is an activity which, in a significant way affect the position of the national legislatures. Since the scope of information provided by the executive authority depends on, indeed, an effectiveness of the control performed by the parliament.

Member States parliaments try to seek the remedy for this phenomenon by monitoring all the government activities, as well as to life properly qualified bodies (parliamentary committees). In addition, they postulate to create the institution composed of national MPs at Community level, which would control activities of the European Union under the legal

\footnotetext{
36 In Greece, it is obligatory that executive bodies are responsible for the introduction to the Greek law of the standards of Community law. As it results from above, it is not a national parliament that makes the transposition of union legal acts. This task belongs to the relevant ministers, who shall adopt arrangements and the President, who exercises the right to issuing a decrees in this range.
} 
account and inspection of acts passed by the Committee and the European Union Council (with the coparticipation of the European Parliament) because of their compliance with the principle of subsidiarity ${ }^{37}$.

As it was stated above, in the majority of member states it is the parliament that decides to appoint special commissions dealing with Community affairs. The scope of competences of such parliamentary committees may differ. Some are exercising the entitlements as the chamber (these committees, in literature, are called quasi-parliaments, for example, Great Commission in Finland «Suuri valiokunta», or Swedish Advisory Commission of the European Union «EU - nämnden», while others occupy an equal position with other committees ${ }^{38}$, for example, the Greek Committee for European Affairs «Epitropi Evropaikon Ypothesseon», and Portuguese Committee for European Affairs «Comissao de Assuntos Europeus».

The composition of the European Union committees, appointed in national parliaments, which are exercising equivalent competences for entitlements of the entire parliament (with the proviso, that these competences, in case of the committees, concern union matters, exclusively), is created with taking into account the balance of forces in the House. His is to determine a certain kind of compensation for reducing entitlements of the parliament for these commissions. ${ }^{39}$

Appointment of the European Union committees depends either on the solution received in a given country, or the articles of the constitution, or resolutions of the House. The rank of the appointing act is points at the position which the committee is occupying in the parliament. ${ }^{40}$

European committees are taking action mainly from the scope of the community policy. But they also have other rights, which are entitled to remaining Parliamentary committees, such as the right to conduct debates over issues commissioned by the chamber as part of the legislative process; right to demand the presence of representatives of the government during

37 D. Olejniczak, op.cit., pp. 14-15

38 They correspond to their position, the range of competence and the way of appointing.

39 R. Grzeszczak, op.cit., pp. 5.

40 Ibidem. 
the deliberations of the committee; the right to ask them questions, work out project, the right to conduct debates on issues which are the subjects of their activities, etc.

It should also be noted that to the efficiency, the effectiveness, as well as the high level the rating of parliamentary committees dealing with the union policy amongst the public opinion undoubtedly affect the substantive excellent preparation of their members to carry out tasks assigned to them. In order to deserve such a big mandate of the public confidence must stand out with the knowledge, primarily in the field of EU law.

National Parliaments, within the framework of their decisive competence, have the power of the state budget's adoption, on the basis of government project. Budget is regulating both all incomes and profits, as well as the state expenditures. Exercising one's entitlements in this area legislative bodies of states of the Fifteen influence simultaneously on shape of budget of the union by determining this its part which constitutes the membership contribution of the given state. Parliaments of EU Member States carrying out one's competences in the sphere of deciding on the state budget (have the right to reject ${ }^{41}$ the whole project, to postulate the changes of its articles, or accept the proposal of the government), are also checking the action of the government in the field led by its financial policy.

How justly notices Van Der Maelen "democratic nature of the Union is not expressed only in a priori and a posteriori control of decisionmaking process at European level, but also in the control of financial flows arising from the implementation taken previously decisions." Actions of administration and national bodies do not enter, however, in this range, in the scope of competences of European Parliament, aren't reporting also, in the considerable part, of control of national parliaments. Should so to create an adequate system of control together with the relevant procedures, which would serve the coordination of activities in this sphere. The system, which would be based on cooperation, mutual exchange of information, exchange of views, making joint decisions, and in the end it would lead

41 In some states rejecting the draft budget can take place only behind the approval of qualified majority of Members of Parliament. 
to establishing the control and procedures of enforcement on community and national rung, guaranteeing the proper realization of budget. ${ }^{42}$

In conclusion, national parliaments in the Communities perform important tasks (although in a different range) resulting from the entitlement to the transposition of legal norms of Union to the internal orders of the Member States, ratify also international treaties, are deciding on the part of the Community budget. Moreover, domestic legislatures control actions of national executives in the European Union, how also thanks to functioning and active participation in the structures of the Communities can indirectly influence in the shape of the European law.

In view of the democratic deficit ${ }^{43}$ affecting the Community institutions (only because the European Parliament, as the sole authority of the EU has direct card) more often heard voices in the doctrine postulating strengthener of the activities of national Parliaments on EU forum. ${ }^{44}$ The course of the discussion provides the evidences for this, also, of discussion led during the works of European convent.

Widening borders of the participation of national representative bodies in the building of European Union has a chance to guarantee democratic basis for the European integration process. Each Member State Communities determine their own ways, methods, as well as the area of activities of Parliaments in the European Union. The above-mentioned various forms of cooperation between the national parliamentary committees and committees of the European Parliament, or between the parliaments as legislative bodies about representative character (COSAC, the Conference of Presidents of Parliaments) are contributing, undoubtedly, are contributing, undoubtedly, for improving the significance of

42 Parliamentary supervision of the community legislature in Great Britain, translation of the report of the member of the Belgian House of Representatives, Van Der Marlen', The Office of the Seym, the Office of Studies and expert opinions, September 1995, Materials and Documents, No. 159, pp. 7-8.

43 G. Laprat thinks that exists in the Union a phenomenon "of double democratic deficit"; from one side parliaments are losing their right-creative entitlements for state governments, from second whereas side the rights of the European Parliament aren't compensating for these losses; see also: T. Biernat, op.cit., pp. 174-175.

44 The described earlier European Convent should be remedy for the deficit of the democracy. 
national parliaments in Communities. Are reducing the institutional imbalance also ruling in the Union, infringing democratic bases both carried out the legislative processes and applied control instruments. ${ }^{45}$

As rightly points out Bronislaw Geremek, experiencing the European integration is showing the need of keeping it balance in the decisionmaking process between national institutions and union institutions (...). The community method requires settling stronger than until now in democratic mechanisms, a larger engagement of the citizens, but therefore also their representative institution - European Parliament." 46

T. Biernat emphasizes however, that the liquidation of the deficit of the democracy is possible at the simultaneous growth in importance of parliaments of member states. "A greater supervision of national parliaments is needed above the European action of governments." 47

Both the national parliaments of EU member states, as the European Parliament, as the legislative bodies having direct legal legitimacy, in direction expansions of one's competences are taking actions and the expansion of influence field on executive organs. The activity of this type of representative organs is leading to the increasing of democratic bases of the communities. Is visible both in the functioning of national parliaments, as well as in postulated and worked out the projects of institutional reforms in European Union, necessary also in consideration of not long ago carried out the sixth already expansion of community structures for a further Member States.

How justly notices Allesandro Missir di Lusignano ${ }^{48}$ the European process can get the democratic excitement only thanks to the double card: direct legitimacy, members of the European Parliament by the nations, and the legitimacy of the governments of the Member States, based on the will of national parliaments, coming from the direct general elections. Lusignano is writing farther, that the European Union formed the unique

45 National parliaments in European integration process, Office of Studies and expert opinions of the Office of the Seym, IP - 54 M.

46 B. Geremek, What Union do we want?, „Gazeta Wyborcza ”, 9-10.03.2002.

47 T. Biernat, op.cit., p. 181.

48 A.M. di Lusignano, The membership in the European Union but the national sovereignty, pp. 37-43. 
system, In which the guarantees a democratic state of law, which are based on our societies, of the Community foundations are also. ${ }^{49}$ Legislative organs, having above on the attention, must be guided by the principles of democracy, both in joint operations at Community Forum, as well as on the inner arena. Only because in this way get and established position, like and skills reflecting the will of the sovereign - the nation, have a chance for getting the social approval, and as a result of the actual implementation.

By L. Laming opinion political scientists, as well as commentators of the political scene, who specialized in searching for divisions between members in the European Convent emphasized the existence of differences in views of large and small countries, of adherents of the centralization and their opponents, like well as national parliamentarians and MEPs. Certainly, however, the most important dividing line ran and runs between those who want to strengthen the role of national parliaments, and those who work to expand of the executive power. ${ }^{50}$

How accurately Marek Borowski is giving serious obstacle to the functioning of the Union may become centrifugal tendencies; in order to prevent it is not permitted to admit to alienation of national Parliaments from Communities questions. If national parliaments are not drawn into the process of building of Europe it is very likely that and more often will begin to occupy the opposition positions to the European institutions. This would create a real danger in the form of a revival of anti-European trends..$^{51} \mathrm{M}$. Borowski also indicates that the role of parliaments in European politics for many years has been underestimated. Democratic deficit in European institutions attempted to overcome extending the powers of the European Parliament. Although does not exhaust the issue. Exclusion of competences of national parliaments in European affairs could lead for alienating them. Would create a kind of monopoly of the government to

49 Ibidem.

50 R. Laming, „Federal Union” Parliamentary democracy In Europe. The European constitutional convention is dealing with some of biggest political issues of our time.

51 M. Borowski, The role of the nationalist parliament and the European Parliament in the decision-making process the EU, kronika.sejm.gov.pl/kronika.2002/test/par-28-4. php?par=4\&srdt=5, 27.06.2003. 
represent countries in the Union and the national parliament perforce would play a role of the system opposition towards integration..$^{52}$

National parliaments should be actively engaged in the affairs of the European Union. The Protocol annexed to the Amsterdam Treaty concerning the role of national parliaments, as well as concrating its articles of the draft of the Constitutional Treaty for Europe, constitute an important forward step. These documents shall constitute important reasons for strengthening the role of national parliaments in the future of the European Union. Modern democracy it is above all a parliamentary democracy. There are various ways of legitimizing the decision making by national and regional authorities. However, Parliaments still remain central elements of all control mechanisms.

Strengthening the position of national parliaments would certainly serve:

- consistent research of initiatives on European level in terms of their compliance with the subsidiarity principle. National parliaments are appropriate to carry out this task, because they do not participate in the Community legislative process, and hence have no self-interest in the course of its process. So their judgements have opinion-forming character, and objective at the same time. Establishment of a flexible procedure of monitoring in the initial stage of the legislative would provide with the fuller inspection of the realization of subsidiarities;

- strengthening the inspection of the activity of the government in the arena the EU. As rightly points out Danuta Hübner "given the relatively large margin of maneuver what sort have government in the questions of EU, national parliaments provide with the muchneeded framework of the reference. In this context, the exchange of information and experiences within the COSAC takes on particular significance. This exchange should be done more effectively and to stretch it to sector parliamentary committees;"

\footnotetext{
52 M. Borowski, Vysehrad to the European Union, 29.01.2003, wwwl.gazeta.pl/ ue/1,36136,1300692.html, 27.06.2003.
} 
- thirdly, national legislators are much needed and irreplaceable link with the citizen. The European Parliament is more involved in the Community decision-making process than national parliaments. A large part of the task of shaping views on European issues is therefore in the hands of members of domestic parliaments ${ }^{53}$;

- extend the field of parliamentary control of the Council members, which, depending on the country and the tradition is carried out by various methods;

- co-operation within COSAC and transfer documentation six weeks in advance;

- moreover, irrespective of the meetings within the framework of COSAC, once month should hold joint meetings of the relevant committees of national parliaments (with participation 1-2 members of parliament of every country $)^{54}$ in important issues for the whole of Europe. These meetings should concern all areas of policies Community. A review of the processes of implementing directives would be their purpose, assessment of the competitiveness of EU given sector on the background of rivalry in global system, as well as monitoring the implementation of common policies and the principle of subsidiarity, information about drafts of new directives. She would be it second, after the Committee of the Regions, horizontal structure in the system of the European Union. This proposal corresponds to the plan of "specialist COSAC-s", moved by the Commission to European matters by the Folketing. ${ }^{55}$ At this point it should be noted that into the doctrine is also reflected different opinions. H. Hololei takes the view that It is in everyone's interest further institutionalization of COSAC. In his opinion the establishment of the Congress consisting of representatives of

53 The contribution of Professor Danuta Hübner, Representative of the Government of the Republic of Poland, to Convent into the discussion on the role of national parliaments, Brussels 07.11.2002, www.futurum.gov.pl/futurum.nsf/0/FC6076AF9D7C637CC1256CED00467AB4,27.06.2003.

54 M. Borowski, Role..., kronika.sejm.gov.pl/kronika.2002/test/par-28-4.php? par $=4 \& \operatorname{srdt}=5,27.06 .2003$.

55 Ibidem. 
national parliaments and the EP European could lead to "institutional structures too difficult for ordinary people;";6

- national parliaments can be useful actors in the common shaping of European integration, since they are primarily all the "centers of political ferment and debates." They contribute the needed contribution to shaping the politics on the European level. According to D.Hübner there are two ways to focus this contribution. Firstly, representatives of national parliaments can be invited to the annual debates on the EU's strategical programme. The European Parliament could be host such debates. Secondly, national parliaments can influence for policy-making in the EU through the mechanisms of constitutional review. ${ }^{57}$

Analyzing the problem of places of national parliaments in the EU must therefore noted that currently the most urgent thing is to settle the problem of strengthening the legislature of the Member States in carrying out control over the representatives of the Council of the European Union.

This can be achieved through the creation of appropriate mechanisms. Rule should therefore be that:

- European Commission provides all legislative proposals to national parliaments;

- The Commission shall forward its legislative programs to Member States;

- Establishes a better exchange of information by strengthening the cooperation within COSAC;

- Create a consultation mechanism, which would involve national parliaments in control system of rules of subsidiarity;

56 Statement by Mr Henryk Hololei Alternte Member of the Estonia on the Role of National Parliaments, Brussels, 28-29 October 2002.

57 The contribution of Professor Danuta Hübner, Representative of the Government of the Republic of Poland Convention into the discussion on the role of national parliaments, Brussels 07.11.2002, www.futurum.gov.pl/futurum.nsf/0/FC6076AF9D7C637CC 1256CED00467AB4, 27.06.2003. 
- National legislators should have the right to control their representatives in the EU Council, but not only through judicial procedures. ${ }^{58}$

From above brightly results, that fuller involvement of national parliaments in the decision-making in the EU system significantly contribute to strengthen of the democratic correctness and it would move closer the Union to its citizens ${ }^{59}$. Strengthening the position of national parliaments raise also, in fact, the level of interest in the European Parliament among voters. Broader discussion on policies and regulations of the Community on the national level certainly would help, in turn, to popularize the knowledge about EU affairs, in the effect whereas is necessary to establish, that would increase interest in elections to the European Parliament (and what hence - attendance during succeeding elections). ${ }^{60}$

The primary problem is the parliamentary control of ministers participating in meetings of the European Union. It seems, that both the European Parliament and the individual national parliaments should work together to strengthen the position of the national legislatures of member states and competences of special organs (i.e. commission for European affairs) in order to have constant supervision over the activities of the executive. For this direction of development is justified by past experience of functioning of the Conference to matters of Organs Specialized in Community Matters, so, in practice, the primary forum for co-operation and contacts between the national parliaments and European Parliament. ${ }^{61}$

With this in mind, the majority of the EP standing committees now consult with their national counterparts through bilateral or multilateral meetings, visits by the Presidents of the Chambers. Political fractions in the EP also maintain contacts with their national counterparts, developing

58 Memorandum of the Benelux Countries on the Future of the European Union Engaging the National Parliaments without Opposing National and European Sovereignty,www.dgap.org/english/tip/tip0301/benelux111202.htm, 27.06.2003.

59 Ibidem.

60 Ibidem.

61 Ibidem. 
them at different levels, depending on national or political party connections. ${ }^{62}$

In conclusion it should be noted that, if national parliaments wish play a major role, in the future, in the structures of the European Union it is necessary to:

- devote more attention to the processes of monitoring the implementation and functioning of European law and should make their conclusions in this respect. Since the European Parliament isn't able alone to check law, should do so through the national parliaments, which in the process will be involved into European issues. A new element could also be to assess the effects of this process at national level;

- their primary role was to monitor and control the use of structural funds by the administration of the country and ensuring their effective use;

- consider the accreditation of observers of the national parliaments to the European Parliament (two MPs - including one of the ruling party, the second from opposition);

- national parliaments have the right to present opinions on the position of national representatives in the organs of the Union. Indeed, the practice in this field are shaped by each country separately, but to establish such a right aggravated the sense of the national parliament for its important influence on decisions of national governments in EU63.

In conclusion one should point, that issue of positions of legislatures of the Member States of the European Union is also of particular importance in view of the one more very important fact. How rightly notes the marshal of the Seym of the Republic of Poland, M. Borowski, in one of his speeches, "foundations of Europe were, are and in the future will be built by nations and parliaments. The effectiveness of the creation of a strong democratic structure of Europe and its favorable image in the eyes of the

\footnotetext{
62 European Parlament Fact Sheets - The European Parlament: relations with the national parliaments, www.europarl.eu.int/factsheets/1 35 en.htm, 27.06.2003.

63 M. Borowski, Role..., www.kronika.sejm.gov.pl/kronika.2002/test/par-28-4.php? par $=4 \& s r d t=5,27.06 .2003$.
} 
citizens of our continent requires the dissemination of thinking in European categories. An example of such thinking should also be national parliaments and into this should also be seen as their role in the future, to be able to meet their particular mission in bringing Union's citizens. ${ }^{64}$

In doctrine is being emphasized a fact beings of "anxieties" emerging due to too violent integration. On the other hand, however, its positive effect is indicatedt in the form of inclusion of many politicians, interest groups, the media and societies in the European debate. They acknowledge that it is the only way to build a bridge between the "European" and the national policy ${ }^{65}$ Moreover, it is suggested that national parliaments should acquire new rights in the European legislative process for the full protection of the principle of subsidiarity, what they go out on against the decisions of Constitutional Treaty.

64 Ibidem.

65 Statement by Mr Henryk Hololei Alternte Member of the Estonia on the Role of National Parliaments - 28-29 October 2002, Brussels. 